\title{
Barriers to Adopting Lean Construction in the Construction Industry-The Case of Jordan
}

\author{
Wassim Al Balkhy ${ }^{1, *(D)}$, Rateb Sweis ${ }^{2}(\mathbb{D})$ and Zoubeir Lafhaj ${ }^{1}$ \\ 1 Laboratoire de Mécanique Multiphysique Multiéchelle, LaMcube, UMR 9013, Centrale Lille, CNRS, \\ Université de Lille, F-59000 Lille, France; zoubeir.lafhaj@centralelille.fr \\ 2 Business Management Department, The University of Jordan, Amman POB 11942, Jordan; r.sweis@ju.edu.jo \\ * Correspondence: wassim.albalkhy@gmail.com or wassim.al-balkhy@centralelille.fr
}

Citation: Al Balkhy, W.; Sweis, R.;

Lafhaj, Z. Barriers to Adopting Lean Construction in the Construction Industry-The Case of Jordan. Buildings 2021, 11, 222. https://doi.org/10.3390/ buildings 11060222

Academic Editor: Patrick Dallasega

Received: 12 April 2021

Accepted: 20 May 2021

Published: 23 May 2021

Publisher's Note: MDPI stays neutral with regard to jurisdictional claims in published maps and institutional affiliations.

Copyright: (c) 2021 by the authors. Licensee MDPI, Basel, Switzerland. This article is an open access article distributed under the terms and conditions of the Creative Commons Attribution (CC BY) license (https:/ / creativecommons.org/licenses/by/ $4.0 /)$.

\begin{abstract}
During the last few decades, there has been a greater understanding of the role of lean construction (LC) in achieving better management of construction projects and enabling the application of the fourth industrial revolution in the construction industry (Construction 4.0), which in turn, has the potential to improve the practices and outcomes in the construction industry. This paper aims to identify the barriers to adopt LC practices by taking a case of the Kingdom of Jordan. A questionnaire that included 30 barriers that were resulted from a comprehensive literature review was distributed and filled by 326 respondents from the Jordanian construction industry. The findings showed that the absence of support from the top management, low awareness toward LC, lack of training, and the absence of transparency are amongst the most serious factors that hinder the adoption of LC. The findings in this paper might be helpful to improve the knowledge about LC and support the adoption of new techniques that might improve the performance in the construction industry.
\end{abstract}

Keywords: lean; lean construction; lean implementation; lean adoption; construction 4.0; barriers; Jordan

\section{Introduction}

Since the early 1990s, and due to the success of lean thinking in manufacturing, noticeable efforts have been made to apply lean thinking or lean construction (LC) in the construction industry. Despite the lack of documentation in some cases, some researchers described the results of LC implementation as "revolutionary" [1]. These results include improvement in cost saving [2-8], profitability for projects parties [3,9], labor productivity $[3,10-13]$, project duration $[3,6-8,14-16]$, quality $[3,4,17]$, safety and accidents rate $[3,4,7-9,11,16]$, sustainability [18-20], collaborative work environment and relationships between partners $[4,7,21-23]$, inventory management $[6,8,24,25]$, site organization $[16,22]$, scheduling and work predictability $[3,6,7,16,21,23]$, job satisfaction [26], and client satisfaction $[3,9,16,17,25]$.

The implementation of LC was noticeable in several areas around the globe such as the United States, United Kingdom, South America, and Scandinavian countries [1,27,28]. Nevertheless, in many countries, lean construction was not welcomed, (e.g., in Japan which is the origin of Toyota production systems where lean was firstly developed), not known, or faced by numerous barriers [29-34].

In Jordan, as a developing country that suffers from the increasing population and the political crises in the region, the construction industry is a critical sector to help the country face these challenges [31]. As well, this sector contributes to about $4.5 \%$ of the national gross domestic product [35]. However, the construction sector in Jordan suffers from several problems that hinders its role as a significant sector to achieve sustainable development in the country. Examples of these problems include, but are not limited to, safety-related problems, delays, poor quality, performance, and productivity, unskilled labor, cost overrun, and reworks [36-43]. As a result, there is a need for a change in the 
way of managing construction projects in Jordan. Accordingly, LC, as a philosophy that proves its effectiveness in many projects and places around the globe, might be one of the needed solutions to solve these problems. In fact, the body of research and studies on LC adoption in Jordan is very limited [31,33].

Therefore, this paper tries to identify the most affecting barriers that face the adoption of LC in Jordan, hoping that this study can contribute to achieving an effective change in the management of the construction projects in Jordan. Furthermore, "lean" is not the specific rules to be used; instead, it is a mindset and culture to be adopted. Hence, identifying the most significant barriers to adopt lean would help to identify the enablers and the strategies to implement this mindset to be more compatible with the Jordanian environment.

\section{Literature Review}

The concept of lean was coined in the Toyota Production System (TPS) in Japan in the 1970s of the last century and moved to the west and the world in the writings of Krafcik [44], and Womack, Johns, and Ross [45,46]. The principles of these systems include $[45,46]$ : (1) Value identification from customer's point of view, (2) Identify value stream, (3) Eliminate wastes and prevent stoppages in the flows within work processes, (4) Customer pull, and (5) Continuous work to achieve perfection. "The Triumph" of lean, as described by Krafcik [44], and the success of lean thinking in manufacturing, encouraged many researchers and practitioners to work to mimic the experience of lean in manufacturing in other sectors; including construction such as aerospace, metal processing, construction industry, and even in services [47,48].

The introduction of lean to the construction industry started in 1992 by Lauri Koskela $[49,50]$ who presented Transformation-Flow-Value (TFV) theory, which has three central concepts; "Transformation", which is transforming the inputs into outputs by decomposing the work into tasks, then minimizing the cost of these undertakings in order to realize the efficiency of the added-value activities. "Flow" of materials and information that includes, in addition to transformation, inspection, moving, and waiting. The main aim of flow design and improvement is minimizing the wastes of non-added value activities. In addition to the "Value" generated from the customer point of view, by ensuring understanding the needs of the customer and fulfillment these needs. In addition to Koskela's work, Ballard [51,52] introduced the Last Planner System (LPS), which is lean tool that was specifically developed in the construction field and aims to create a social process based on discussion between planning and site staff to have a reliable workflow [53]. LPS is the most well-known lean construction tool for planning and control. Sometimes, it is even used as a synonym for the term lean construction [54] and is used as a practical tool to understand the lean thinking application in the construction industry [53].

Since the introduction of lean thinking in construction, several definitions were presented for the LC. In their review, and based on reviewing some of the available definitions for LC, Albalkhy and Sweis [34] defined LC as "a philosophy that aims to improve the collaboration between all project stakeholders to maximize value for all of them in general and for the customer in particular. In addition to eliminating all kind of wastes, achieving continuous improvement, improving flow of materials, reducing cost and enhancing safety and quality". Accordingly, lean construction can be seen as a social system that gathers different stakeholders in the project to achieve the value for them and for the customer. This can be seen when finding collaboration that governs most of the LC tools and practices [34]. However, this industry is characterized as a fragmented industry, in which stakeholders are working together but have different objectives and perspectives about work $[55,56]$, which in turn, causes reluctance for collaboration between them [3,18,21-23,57-64]. Therefore, in order to study the barriers to adopt a collaborative-based philosophy and to achieve a change in the construction culture, it is worthy to understand the perspectives of different stakeholders in the industry about this philosophy. Hence, this study aims to answer the following research questions: 
Do contractors, consultants, and owners have different views about the barriers facing the adoption of LC?

\section{Research Methodology}

The literature includes numerous studies about barriers that face the adoption of lean construction $[3,21,28,34,55,59,60,63-76]$. However, there is no study about this topic in Jordan. Additionally, the current study is different from the previous studies by its endeavor to assess the barriers from the perceptions of different stakeholders in the industry.

The only study that is available about this topic in Jordan is another paper from the same project [34], in which a systematic literature review (SLR) was conducted to identify the list of the problems that face the adoption of LC in general; without any geographic determination. SLR was based on reviewing 117 studies from different countries about the experiences of LC implementation and adoption in peer-reviewed scientific journals in the following databases: "Emerald Insight, Wiley Online Library, Science Direct, Taylor \& Francis, Springer Link, ASCE Library, SAGE Journals". In addition to the Lean Construction Journal, the annual conference papers of the International Group of Lean Construction (IGLC), and some seminal studies about lean. The results of the SLR were identifying and thoroughly explaining 29 barriers that LC adoption faces. The same paper classified barriers into three groups:

- Internal environment-related.

- Input (labor and materials)-related.

- Exogenous.

This study aims to validate this model by taking the case of Jordan and to identify the most affecting barriers on lean construction adoption from the perspectives of different stakeholder groups working in construction, namely, owners, contractors, and consultants. The list of the identified barriers and the classification of these barriers can be found in Table 1.

Table 1. List of the barriers that face the adoption of lean construction [34].

\begin{tabular}{|c|c|}
\hline Classification & Barrier \\
\hline \multirow{14}{*}{ Barriers Related to the Internal Environment } & Poor understanding of the customer needs and lack of customer focus (IE1) \\
\hline & Management resistance to change (IE2) \\
\hline & Lack of support and commitment from top management (IE3) \\
\hline & Lack of involvement and transparency among stakeholders (IE4) \\
\hline & Lack of adequate lean awareness and understanding (IE5) \\
\hline & $\begin{array}{l}\text { The results are not fast and often only partially visible, and may not conform with high } \\
\text { expectations from management (IE6) }\end{array}$ \\
\hline & Lean may lead to additional cost/Implementation cost (IE7) \\
\hline & $\begin{array}{l}\text { Inaccurate and incomplete designs, and lack of applying the concept of design } \\
\text { constructability (IE8) }\end{array}$ \\
\hline & The reluctance of project participants to share risks (IE9) \\
\hline & Lack of a long-term philosophy and planning (IE10) \\
\hline & Lack of planning for quality (IE11) \\
\hline & Poor leadership and insufficient management skills (IE12) \\
\hline & Lack of incentives and motivation and poor professional wages (IE13) \\
\hline & $\begin{array}{c}\text { Inadequate administration of the necessary information to generate a learning cycle and take } \\
\text { corrective actions (IE14) }\end{array}$ \\
\hline
\end{tabular}


Table 1. Cont.

\begin{tabular}{|c|c|}
\hline Classification & Barrier \\
\hline & Hierarchies in organizational structures/Unsuitable organizational structure (IE15) \\
\hline & $\begin{array}{c}\text { Centralization of the decision and avoid making decisions and taking responsibility from } \\
\text { those who are not in the top management (IE16) }\end{array}$ \\
\hline & Lack of identification and control of waste (IE17) \\
\hline \multirow{5}{*}{ Barriers Related to Input Factors (Labor) } & Employees resistance to change and fear of unfamiliar practices (L1) \\
\hline & Unskilled labor and the low level of education of the site foreman (L2) \\
\hline & Insufficient training for workers (L3) \\
\hline & Labor consider lean too complex (L4) \\
\hline & High turnover of workforce (L5) \\
\hline \multirow{3}{*}{ Barriers Related to Input Factors (Materials) } & Inadequate delivery performance and the delays in materials delivery (M1) \\
\hline & Lack of long-term relationship with suppliers (M2) \\
\hline & Limited use of off-site construction techniques and the lack of prefabrication (M3) \\
\hline \multirow{4}{*}{ Exogenous Barriers } & $\begin{array}{l}\text { Fragmented nature of the construction industry/so many parties joined the project, } \\
\text { especially subcontractors and suppliers (EX1) }\end{array}$ \\
\hline & Limited use of design-and-build procurement (EX2) \\
\hline & Stringent requirements and approvals during contracting (EX3) \\
\hline & Lack of support from the government (EX4) \\
\hline
\end{tabular}

\subsection{Research Design and Data Collection}

This study adopted the quantitative approach by using a questionnaire to investigate data collection. The use of descriptive design is widespread in social and business sciences, where researchers aim to describe a state by measuring or assessing items or by investigating causes even without intervention or controlling variables [77]. As well, the quantitative methods of data collection are popular in managerial studies, as they help researchers obtain quantitative insights about personal perceptions and organizational policies and practices $[33,78,79]$. Furthermore, many researchers have used this type of design to study the barriers to adopting lean construction $[61,63,67,69-71,80]$. Additionally, this approach was seen as useful to get quantitative comparisons and assess the significant differences between different perspectives of the groups of stakeholders aiming at answering the two research questions. The questionnaire comprises three parts. The first part aimed to collect some demographic data about the participants and their companies. The second part was to rank the barriers using 5-Likert scale statements.

The questionnaire was translated into Arabic and then it was delivered to respondents or sent by email or LinkedIn accounts via an online survey using Google Forms.

\subsection{Population and Sample}

The population includes professionals working in the Jordanian construction industry, which mainly can be classified into three groups: contractors, consultants, and owners. To select the sample of the study, the authors chose random sampling as a recruitment method for the sample. The use of this technique helps to obtain results that are similar (to a good extent) to those found if taking the whole population and gives equal opportunities for all population members to participate. While using this technique, the authors obtained lists of engineers and contractors from The Jordanian Construction Contractors Association (JCCA) and the Jordanian Engineers Association (JEA). Then, a random sample of the participants was selected using random numbers generator in Microsoft Excel. Using the sample size calculator in "Survemonkey.com; accessed date 15 May 2021", with an infinite number of population, confidence level of $95 \%$, and margin error of $5-6 \%$, the required sample size was between 267 and 383 participants. After contacting the list of participants, 326 questionnaires were filled and valid; 41 owners, 107 consultants, and 178 contractors. 


\subsection{Validity Test}

\subsubsection{Content Validity}

The content validity of the questionnaire was ensured by building the questionnaire based on the barriers that were found in the past studies. Additionally, the questionnaire was initially distributed to six professors in the field of construction management. Based on the expert's feedback and comments, the questionnaire was modified. One of the comments that was shared by the experts was adding "the high rates of the worker's absence" to the barriers list. A barrier that is related to the local culture in the construction industry, influences the labor availability and commitment, and causes a shortage of labor, which, in turn, was found to be an affecting factor in Jordan on delays [39,40,81], cost [81,82], change orders [83], and contractors performance [84]. The questionnaire was modified and changed accordingly, and this barrier was added to the labor-related barriers.

\subsubsection{Construct Validity}

Construct validity of a measurement tool aims to assess the consistency of the results obtained with the theory used to design this tool [85]. According to Sekaran and Bougie [85], construct validity can be established by conducting factor analysis.

Factor analysis is one of the multivariate statistical techniques that aims at defining the common dimensions for a set of variables based on analyzing the correlation between these variables. These dimensions are known as factors [86].

Exploratory actor analysis (EFA) can be used to reduce the factors that gather a set of variables and to categorize objects into a homogenous group [87]. Therefore, EFA was employed to examine the inter-relations between the barriers.

According to this model, barriers were categorized into four groups, internal environment-related barriers (17 barriers), labor-related barriers (6 barriers), materialsrelated barriers ( 3 barriers), and exogenous barriers ( 4 barriers). For the simplicity and readability of the tables, the barriers were coded as IE1 to IE17, L1 to L6 (where L6 is the "the high rates of the worker's absence"), M1 to M3, and EX1 to EX 4. Where IE refers to internal environment, $\mathrm{L}$ refers to labor, $\mathrm{M}$ refers to materials, and $\mathrm{EX}$ refers to exogenous (Table 1).

Prior to conducting EFA, Kaiser-Maier-Olkin (KMO) measure and Bartlett's test of sphericity was used to test the sample adequacy and the correlation between the variables [88]. KMO was higher than $0.5(0.885)$, and the correlation matrix was not an identity matrix (approx. Chi-square $=4755.743, p$-value $=0.000$ ). Therefore, it can be said that the factor analysis is useful with these data, and the sample is adequate to conduct it. Using a loading of 0.4 , and Varimax rotation, the results of EFA analysis showed that the barriers can be classified into two factors, as shown in Table 2 .

EFA shows that the barriers IE13 to IE17 were gathered with the labor-related, materialsrelated, and exogenous barriers, while the barriers IE1 to IE10 were gathered in the second group.

Reconsidering the meanings of the barriers (IE13 to IE17) showed that these factors are either related to the organizational structure (IE15) or more related to the employees and middle management tasks (IE13, IE14, IE15, IE17). Therefore, this study adopted the results of the EFA to cluster the barriers in two groups; the first is related to the internal environment, namely, the contractors, the owners, and the consultants (IE1 to IE12), while the second group includes all other groups, employees, structure, labor, materials, and exogenous. In other words, the barriers were clustered in two groups; internal environmentrelated barriers (IE), and non-internal environment-related barriers (non-IE). 
Table 2. Exploratory factor analysis-rotated factor matrix.

\begin{tabular}{|c|c|c|}
\hline \multirow{2}{*}{ Barrier } & \multicolumn{2}{|c|}{ Factor } \\
\hline & 1 & 2 \\
\hline IE1 & 0.482 & \\
\hline IE2 & 0.615 & \\
\hline IE3 & 0.583 & \\
\hline IE4 & 0.609 & \\
\hline IE5 & 0.644 & \\
\hline IE6 & 0.598 & \\
\hline IE7 & 0.531 & \\
\hline IE8 & 0.672 & \\
\hline IE9 & 0.673 & \\
\hline IE10 & 0.777 & \\
\hline IE11 & 0.704 & \\
\hline IE12 & 0.636 & \\
\hline IE13 & & 0.537 \\
\hline IE14 & & 0.561 \\
\hline IE15 & & 0.561 \\
\hline IE16 & & 0.591 \\
\hline IE17 & & 0.484 \\
\hline L1 & & 0.508 \\
\hline L2 & & 0.593 \\
\hline L3 & & 0.598 \\
\hline L4 & & 0.557 \\
\hline L5 & & 0.574 \\
\hline L6 & & 0.58 \\
\hline M1 & & 0.553 \\
\hline M2 & & 0.619 \\
\hline M3 & & 0.646 \\
\hline EX1 & & 0.505 \\
\hline EX2 & & 0.602 \\
\hline EX3 & & 0.674 \\
\hline EX4 & & 0.619 \\
\hline
\end{tabular}

\subsection{Reliability Test}

Reliability is a test of the consistency of the research tool across the time and along its items [85]. To test the internal consistency reliability, Cronbach's alpha was used. The coefficient takes a value between zero and one. The value of 0.6 or more indicates the absence of reliability concerns [86]. Table 3 shows that Cronbach's alpha for all contrasts of the study is greater than 0.6 , which shows that the used instrument is reliable. 
Table 3. Cronbach alpha coefficients.

\begin{tabular}{|c|c|c|c|}
\hline \multicolumn{2}{|c|}{ Study Contrast } & Cronbach's Alpha & Number of Items \\
\hline \multirow{6}{*}{ Before EFA } & $\begin{array}{c}\text { Internal Environment } \\
\text { Barriers }\end{array}$ & 0.886 & 17 \\
\hline & $\begin{array}{l}\text { Labor-Related } \\
\text { Barriers }\end{array}$ & 0.792 & 6 \\
\hline & $\begin{array}{c}\text { Material- Related } \\
\text { Barriers }\end{array}$ & 0.780 & 3 \\
\hline & $\begin{array}{l}\text { Barriers- Related to } \\
\text { Input Factors }\end{array}$ & 0.842 & 9 \\
\hline & Exogenous Barriers & 0.808 & 3 \\
\hline & All Barriers & 0.916 & 30 \\
\hline \multirow{3}{*}{ After EFA } & $\begin{array}{c}\text { Internal Environment } \\
\text { Barriers }\end{array}$ & 0.894 & 12 \\
\hline & Exogenous Barriers & 0.906 & 18 \\
\hline & All Barriers & 0.916 & 30 \\
\hline
\end{tabular}

\subsection{Data Analysis}

The data analysis was performed using the statistical package for the social science (SPSS) version 23.0. In addition to the percentages and frequencies of the respondents and the companies, means and standard deviations were calculated to describe the perceptions of the respondents regarding the barriers to adopting lean construction in Jordan. In addition, analysis of variance (one-way ANOVA) was employed to test the differences in barriers evaluation between the different groups of stakeholders.

\section{Results}

\subsection{The Demographic Profile}

Table 4 shows the demographic profile. The table shows that the respondents are from different groups in term of their experiences. It also shows that most of the respondents have a bachelor degree $(75.8 \%)$, and around half the respondents were the real implementers on-site, as they were contractors (54.6\%). As shown in the table, more than $50 \%$ of respondents were from the contracting companies. In addition, the table shows that the respondents occupy different positions, and around half of them, were working in residential projects.

\subsection{Descriptive Analysis of the Barriers}

Table 5 shows that the contractors have positive attitudes toward all the barriers' questions, as the means were greater than three. In addition, it shows that the contractors accepted "the lack of involvement and transparency among stakeholders (IE4)" (4.02), "insufficient training for workers (L3)" (3.94), "lack of support and commitment from top management (IE3)" (3.84), "inadequate administration of the necessary information to generate a learning cycle and take corrective actions (IE14)" (3.82), and "lack of adequate lean awareness and understanding (IE5)" (3.82) as the most significant barriers. 
Table 4. The demographic profile.

\begin{tabular}{|c|c|c|c|}
\hline & & Frequencies & Percentages $(\%)$ \\
\hline \multirow{4}{*}{ Years of experience } & less than 5 years & 127 & 39.0 \\
\hline & 5-10 years & 75 & 23.0 \\
\hline & 10-15 years & 56 & 17.2 \\
\hline & more than 15 years & 68 & 20.9 \\
\hline \multirow{4}{*}{ Education level } & bachelor & 247 & 75.8 \\
\hline & master & 72 & 22.1 \\
\hline & $\mathrm{PhD}$ & 2 & 0.6 \\
\hline & other & 5 & 1.5 \\
\hline \multirow{3}{*}{ Company type } & Contractor & 178 & 54.6 \\
\hline & consultant & 107 & 32.8 \\
\hline & owner & 41 & 12.6 \\
\hline \multirow{6}{*}{ Position } & company manager & 35 & 10.7 \\
\hline & project manager & 60 & 18.4 \\
\hline & construction manager & 27 & 8.3 \\
\hline & site engineer & 83 & 25.5 \\
\hline & office engineer & 96 & 29.4 \\
\hline & other & 25 & 7.7 \\
\hline \multirow{5}{*}{$\begin{array}{l}\text { Types of projects the } \\
\text { respondents are } \\
\text { working on }\end{array}$} & residential & 159 & 48.8 \\
\hline & infrastructure & 42 & 12.9 \\
\hline & industrial & 47 & 14.4 \\
\hline & public & 41 & 12.6 \\
\hline & others & 37 & 11.3 \\
\hline
\end{tabular}

The table also shows that the consultants have positive attitudes toward all the barriers' questions, as the means were greater than three. In addition, it shows that, from the consultants' points of views, the most significant barriers are "lack of support and commitment from top management (IE3)" (4.05), "insufficient training for workers (L3)" (3.99), "lack of adequate lean awareness and understanding (IE5)" (3.99), "lack of long-term philosophy and planning (IE10)" (3.95), and "inadequate administration of the necessary information to generate a learning cycle and take corrective actions (IE14)" (3.91).

The table also shows that owners have positive attitudes toward all the barrier's questions, as the means are greater than three. In addition, it shows the owners accepted the "lack of support and commitment from top management (IE3)" (4.12), the "lack of adequate lean awareness and understanding (IE5)" (4.12), "inadequate administration of the necessary information to generate a learning cycle and take corrective actions (IE14)" (4.10), "insufficient training for workers (L3)" (4.02), and the "lack of incentives and motivation and poor professional wages (IE13)" (4.00) as the most significant barriers. 
Table 5. Descriptive analysis.

\begin{tabular}{|c|c|c|c|c|c|c|}
\hline Barrier & Overall Average & $\begin{array}{c}\text { Average } \\
\text { (Contractors) }\end{array}$ & $\begin{array}{c}\text { Average } \\
\text { (Consultants) }\end{array}$ & $\begin{array}{l}\text { Average } \\
\text { (Owners) }\end{array}$ & $\mathbf{F}$ & Sig. \\
\hline \multicolumn{7}{|c|}{ Internal environment-related barriers } \\
\hline IE1 & 3.54 & 3.43 & 3.64 & 3.73 & 2.174 & 0.115 \\
\hline IE2 & 3.71 & 3.56 & 3.87 & 3.95 & 3.512 & 0.031 \\
\hline IE3 & 3.94 & 3.84 & 4.05 & 4.12 & 2.052 & 0.130 \\
\hline IE4 & 3.97 & 4.02 & 3.90 & 3.93 & 0.544 & 0.581 \\
\hline IE5 & 3.91 & 3.82 & 3.99 & 4.12 & 1.724 & 0.180 \\
\hline IE6 & 3.49 & 3.46 & 3.50 & 3.59 & 0.320 & 0.726 \\
\hline IE7 & 3.64 & 3.56 & 3.74 & 3.73 & 1.471 & 0.231 \\
\hline IE8 & 3.75 & 3.63 & 3.88 & 3.93 & 2.414 & 0.091 \\
\hline IE9 & 3.67 & 3.62 & 3.66 & 3.93 & 1.526 & 0.219 \\
\hline IE10 & 3.81 & 3.69 & 3.95 & 3.95 & 2.300 & 0.102 \\
\hline IE11 & 3.67 & 3.61 & 3.74 & 3.73 & 0.619 & 0.539 \\
\hline IE12 & 3.66 & 3.65 & 3.64 & 3.73 & 0.115 & 0.892 \\
\hline \multicolumn{7}{|c|}{ Non-Internal environment-related barriers } \\
\hline IE13 & 3.73 & 3.67 & 3.71 & 4.00 & 1.450 & 0.236 \\
\hline IE14 & 3.88 & 3.82 & 3.91 & 4.10 & 1.046 & 0.353 \\
\hline IE15 & 3.32 & 3.31 & 3.33 & 3.34 & 0.017 & 0.983 \\
\hline IE16 & 3.76 & 3.72 & 3.78 & 3.85 & 0.250 & 0.779 \\
\hline IE17 & 3.40 & 3.34 & 3.42 & 3.63 & 1.137 & 0.322 \\
\hline L1 & 3.53 & 3.49 & 3.57 & 3.59 & 0.200 & 0.819 \\
\hline L2 & 3.63 & 3.67 & 3.57 & 3.63 & 0.235 & 0.791 \\
\hline L3 & 3.97 & 3.94 & 3.99 & 4.02 & 0.153 & 0.858 \\
\hline $\mathrm{L} 4$ & 3.33 & 3.33 & 3.23 & 3.56 & 1.424 & 0.242 \\
\hline L5 & 3.33 & 3.31 & 3.36 & 3.34 & 0.049 & 0.952 \\
\hline L6 & 3.21 & 3.22 & 3.21 & 3.12 & 0.143 & 0.866 \\
\hline M1 & 3.38 & 3.29 & 3.44 & 3.61 & 1.585 & 0.207 \\
\hline M2 & 3.61 & 3.50 & 3.77 & 3.71 & 2.447 & 0.088 \\
\hline M3 & 3.55 & 3.41 & 3.71 & 3.73 & 3.509 & 0.031 \\
\hline EX1 & 3.47 & 3.36 & 3.64 & 3.54 & 2.144 & 0.119 \\
\hline EX2 & 3.76 & 3.70 & 3.81 & 3.88 & 0.658 & 0.519 \\
\hline EX3 & 3.54 & 3.47 & 3.62 & 3.61 & 0.751 & 0.473 \\
\hline EX4 & 3.54 & 3.51 & 3.47 & 3.83 & 1.483 & .229 \\
\hline
\end{tabular}

\subsection{Differences in the Evaluation of the Barriers}

To test the differences in barriers' evaluation among the three different groups of stakeholders, ANOVA was employed. Table 5 shows the results of ANOVA tests. The table shows that P-value is larger than $\alpha=0.05$ for all barriers except for two barriers, one is related to the internal environment, which is "the management resistance to change (IE2)" (0.031), and the other is not related to the material, which is "the limited use of off-site construction techniques and the lack of prefabrication (M3)" (0.031). Therefore, it can be said that the contractors, the consultants, and the owners had the same understanding of the significance of hindrance for most barriers. 
To understand the difference between the three groups regarding the two barriers, post hoc analysis was conducted. Different analyses were conducted, namely, Tukey, Bonferroni, Scheffe, Fisher's least significant difference (LSD), the differences were found negligible in most of these analyses, except LSD. While applying LSD, the more comparisons are made, the higher cumulative error is expected, except for the case of having only three treatment groups [89]. As the comparison, in this case, is between three groups, the error of LSD was tolerable. Table 6 shows the results of the post hoc analysis using LSD for the two barriers. The table shows that the contractors have different perceptions regarding the two barriers from the perceptions of the owners and the consultants, as the means of their answers to these barriers statistically differ (less than) from the means of the answers of the consultants and contractors.

Table 6. Post hoc analysis.

\begin{tabular}{|c|c|c|c|c|c|}
\hline Dependent Variable & (I) Company & (J) Company & Mean Difference (I-J) & $\begin{array}{l}\text { Std. } \\
\text { Error }\end{array}$ & Sig. \\
\hline \multirow{6}{*}{$\begin{array}{l}\text { Management resistance } \\
\text { to change }\end{array}$} & \multirow{2}{*}{ contractor } & consultant & $-0.3130^{*}$ & 0.1408 & 0.027 \\
\hline & & owner & $-0.3950 *$ & 0.1994 & 0.048 \\
\hline & \multirow{2}{*}{ consultant } & contractor & $0.3130 *$ & 0.1408 & 0.027 \\
\hline & & owner & -0.0821 & 0.2114 & 0.698 \\
\hline & \multirow{2}{*}{ owner } & contractor & 0.3950 * & 0.1994 & 0.048 \\
\hline & & consultant & 0.0821 & 0.2114 & 0.698 \\
\hline \multirow{6}{*}{$\begin{array}{l}\text { Limited use of offsite } \\
\text { construction techniques }\end{array}$} & \multirow{2}{*}{ contractor } & consultant & $-0.3002 *$ & 0.1272 & 0.019 \\
\hline & & owner & $-0.3216^{*}$ & 0.1601 & 0.045 \\
\hline & \multirow{2}{*}{ consultant } & contractor & $0.3002 *$ & 0.1272 & 0.019 \\
\hline & & owner & -0.0214 & 0.1910 & 0.911 \\
\hline & \multirow{2}{*}{ owner } & contractor & $0.3216^{*}$ & 0.1601 & 0.045 \\
\hline & & consultant & 0.0214 & 0.1910 & 0.911 \\
\hline
\end{tabular}

* Significant at the 0.05 level.

\section{Discussion}

To identify the most severe problems facing the adoption of lean construction principles in construction, 30 barriers were used based on a SLR in the questionnaire. Respondents from the three main groups in the construction sector in Jordan; the contractors, the consultants, and the owners participated in this study and filled 326 questionnaires. The barriers were categorized into three categories; internal environment-related barriers, input factors-related barriers (labors and materials), and exogenous barriers. Nevertheless, after conducting the exploratory factor analysis, the barriers were categorized into two groups; internal environment-related barriers, and non-internal environment-related barriers. The latter included the barriers that were related to labors, materials, exogenous barriers, and the barriers that were related more to mid-management and organization structure.

The respondents agree with all barriers, as the means for all the barriers were higher than three on a five Likert-scale.

The results showed that the three groups have similar perceptions regarding the significance of the hindrances. Both owners and consultants ranked the "lack of support and commitment from top management" as the most significant barrier affecting lean adoption in the Jordanian construction industry. This barrier was ranked as third by the contractors. This barrier was found in numerous studies, either as a significant barrier or as a significant enabler to adopting lean as the role of top management is very significant to support change by involving in work and allocating enough resources and time to implementing lean $[21-23,55,58-60,62-64,67,69,70,76,90-96]$. This can also be explained by much dependence on top-down management where the change is not that easy if it came 
from the low and middle levels. In addition, a large number of construction organizations in Jordan, if not governmental, are family-run, where the owner is the manager and the decision maker [37], and in many cases, this manager lacks the experience in business administration [97].

Another critical factor was the "insufficient training for workers". Both contractors and consultants ranked this barrier as the second barrier, while the owner ranked it as the fourth. This barrier was found in many studies, as training workers is very significant to support adoption of the new culture and encouraging employees' involvement [21,22,61$64,69,75,80,95,98-104]$. In Jordan, the lack of having trained and skilled workers was a significant factor affecting many issues like delays [39], and contractors' performance [84]. However, despite the very important role workers' training plays in improving construction companies' performance [105], the high dependence on the workers, and the high need of their skills, the appreciation of their role is not sufficient. Most companies do not provide training for them as found by Sweis, et al. [31] and Albalkhy and Sweis [33], and this is not only related to lean, for instance, Alkilani, et al. [37] asserted that in case of safety, construction companies in Jordan consider worker training as a waste of resources.

Another significant factor that inhibits lean adoption in Jordan is "the lack of adequate awareness and knowledge about lean". It was the second barrier according to the owners, the third according to the consultant, and the fifth according to the contractors. The lack of lean training centers and the lack of formal education about lean construction in Jordan led to increasing this problem. However, this issue is not only found in Jordan, but also was found in most studies about lean construction obstacles $[28,48,55,57,63,64,69$ 71,76,96,101,106-109].

"Inadequate administration of the necessary information to generate a learning cycle and take corrective actions" was ranked as the third by the owners, the fourth by the contractors, and the fifth by the consultants. This barrier was mainly related to the issue of generating a large quantity of information during construction, but without having the effective management of this information, or without generating learning lessons for the future projects $[21,61,65,110,111]$. The significance of this barrier can be explained by the lack of the culture of the continuous improvement in the Jordanian construction industry as discussed in the studies of Sweis, et al. [31] and Albalkhy and Sweis [33] who found low levels of the continuous improvement culture among the Jordanian construction contractors, and Sweis, et al. [112] who found similar results among the Jordanian construction consultants who are certified with ISO-9001.

"The lack of involvement and transparency from stakeholders" received the highest ranking by the contractors, the sixth by the consultants, and the eighth by the owners. This barrier was found in several studies [3,18,21-23,57-64]. Even though more analysis showed insignificant differences between the three groups in their perceptions toward this barrier, the high ranking of it among the contractors particularly can be explained by the sequential and separated type of works, due to the traditional contractual relationships. The contractors are usually left on the site without much support from other parties, the owners in many cases lack the site work experience, and the consultants prefer to turn their attention toward new projects once the design phase is completed. The contractors then are supposed to deal with many change orders by the owner and uncompleted design by the consultants. In addition, the type of relationships between the three parties is full of conflict, according to Sweis, et al. [39], contractors in Jordan, in most cases, believe that the late payments from the owners are the reason behind their financial difficulties. Similarly, Abbasi, et al. [97] found that the Jordanian contractors from the first and the second grade believe that the lack of real supervision from consultants on site is among the most critical factors that affect their work, and the second-grade contractors particularly suffer from the lack of support from the owners. On the other hand, the owners and the consultants believed that the lack of proper planning and scheduling by the contractors is the reason behind the delays in projects [39], the poor contractors' performance [84], and the poor labor productivity [113], and the failure of construction projects in Jordan [114]. 
The analysis also showed the following barriers as significant: "lack of a long-term philosophy and planning", "management resistance to change", "lack of incentives and motivation and poor professional wages", "limited use of design-and-build procurement", and "inaccurate and incomplete designs, and lack of applying the concept of design constructability".

The lowest rankings were given to the following barriers "high rates of workers absence", "hierarchies in organizational structures/unsuitable organizational structure", "labor consider lean too complex", and "high turnover of workforce".

The differences between perceptions of the three groups regarding all barriers were insignificant, except for two barriers; "the management resistance to change", and "the limited use of offsite construction techniques and the lack of prefabrication". The contractors had less ranking for the two barriers. Further investigation showed that the lowest rankings for the first barrier were from the contractors who are working on public projects and belong to the fourth, fifth, or sixth grade. While for the second barrier, the same group and the contractors from the residential projects and the third grade gave the lowest ranking.

\section{Conclusions}

As lean construction is evolving and showing effectiveness in several places around the globe, it is necessary to study the challenges its adoption faces, especially in the countries where this philosophy is not well-known or formally practiced. This study uses Jordan as a case to study the most affecting barriers using the perceptions of different stakeholders in the industry; the contractors, the owners, and the consultants.

The results showed that those groups have similar perceptions about the problems facing lean adoption in Jordan. The most significant barriers to adopting lean were "the lack of support from top management", "insufficient training for workers", "lack of adequate lean awareness and understanding", "inadequate administration of the necessary information to generate a learning cycle and take corrective actions", and "the lack of involvement and transparency among stakeholders".

Other vital barriers were "lack of a long-term philosophy and planning", "management resistance to change", "lack of incentives and motivation and poor professional wages", "limited use of design-and-build procurement", and "inaccurate and incomplete designs, and lack of applying the concept of design constructability".

Therefore, to improve the adoption of lean construction in Jordan, some of the strategies can be suggested: Firstly, management of the construction companies should take the lead in the change and adopt new methods that can help to increase the efficiency and improve the performance of industry. Secondly, government and universities, in cooperation with associations, should support the knowledge about lean construction in Jordan. For this purpose, new formal education programs and workshops in the universities can be established, new training centers or programs can be initiated, and more reports can be published to raise the awareness of lean. Thirdly, managements should support the involvement and the innovation of the employees from different levels by providing training programs, motivating and empowering them, and supporting their feedback. Fourthly, implementing lean construction, even on small scales, to increase the recognition of its benefits and challenges. By sharing the results of these experiences, more companies can feel the extent to which they fit the lean principles. Fifthly, support for building trust and enhancing the communication between all stakeholders in the projects. Early involvement of contractors, partnering, and concurrent engineering can help to support this point. Finally, more dependence on new procurements and contracts types rather than sticking to use design-bid-build would help to support the cooperation and mitigate the conflicts between the stakeholders.

The results in this study show that despite the differences in the objectives, roles, and nature of works between the contractors, consultants, and owner, the three groups have similar or close ideas about the barriers facing this LC. Accordingly, although the results are related to this case and to Jordan; however, they show possibilities of having united ground between the three groups regarding their perceptions and understanding of LC. 
This might be a positive indicator about the possibilities of creating connections between these groups and more future collaboration. Nevertheless, this hypothesis needs more investigation to be accepted or rejected.

This study is not free of limitation. The first limitation is that this study considered the adoption of lean construction in general. The current study did not investigate the barriers that face specific lean tool or technique (e.g., Last Planner System). Accordingly, future studies are needed to study the implementation and the barriers that face one specific tool or more. The second limitation is the use of survey; even though the use of survey is very common while studying the factors affecting a specific phenomenon or subject, it is recommended to conduct future studies that employ interviews where participants can thoroughly express the root causes for the problems, or case studies where it is possible to study the real implementation and the barriers facing it. Furthermore, EFA was used to validate the barriers. Hence, it is recommended to apply the model of this study on other samples to validate the model using confirmatory factor analysis. Finally, to improve the awareness and overall understanding of lean, further studies can be conducted to define tools and the challenges facing lean education in Jordan and other countries.

The findings of the current investigation might be helpful to improve the ways of managing construction projects not only in Jordan but also in other countries that might share some similarities with Jordan. Companies can also adopt the used tool to measure their readiness to adopt lean construction, to get insights about the factors that are needed while implementing lean construction, or to study the barriers that face the implementation process of lean construction. Accordingly, these companies can develop strategies that can improve the adoption and implementation of this philosophy.

Author Contributions: W.A.B. designed the model of the study and carried out the data collection and data analysis. R.S. is professor in project management. He is the supervisor of the work. He supervised the work and contributed to the design of the model and reviewing the analysis of the study. Z.L. is professor in construction 4.0 practices and lean construction. He reviewed the paper on several occasion and contributed in the discussion of the model and the results. All authors have read and agreed to the published version of the manuscript.

Funding: This research received no external funding.

Institutional Review Board Statement: Not applicable.

Informed Consent Statement: Not applicable.

Data Availability Statement: The data presented in this study are available on request from the corresponding author.

Conflicts of Interest: The authors declare no conflict of interest.

\section{References}

1. Jørgensen, B.; Emmitt, S. Lost in transition: The transfer of lean manufacturing to construction. Eng. Constr. Archit. Manag. 2008, 15, 383-398. [CrossRef]

2. Wodalski, M.J.; Thompson, B.P.; Whited, G.; Hanna, A.S. Applying lean techniques in delivery of transportation infrastructure construction projects. In Proceedings of the 18th International Group for Lean Construction Conference, Haifa, Israel, 14-16 July 2010; pp. 609-619.

3. Mossman, A. Why isn't the UK construction industry going lean with gusto? Lean Constr. J. 2009, 13-23. Available online: https:/ / www.leanconstruction.org/media/library/id39/Why_Isn\%E2\%80\%99t_The_UK_Construction_Industry_Going_ Lean_With_Gusto.pdf (accessed on 14 April 2019).

4. Simonsson, P.; Emborg, M. Industrialization in Swedish bridge engineering: A case study of lean construction. In Proceedings of the 15th International Group for Lean Construction Conference, East Lansing, MI, USA, 18-20 July 2007; pp. $244-253$.

5. Koerckel, A.; Ballard, G. Return on Investment in Construction Innovation-A Lean Construction Case Study. In Proceedings of the 13th International Group for Lean Construction Conference, Sydney, Australia, 19-21 July 2005; pp. 91-98.

6. Mohan, S.B.; Iyer, S. Effectiveness of lean principles in construction. In Proceedings of the 13th Annual Conference of the International Group for Lean Construction, Sydney, Australia, 19-21 July 2005; pp. 421-429.

7. Salem, O.; Solomon, J.; Genaidy, A.; Minkarah, I. Lean construction: From theory to implementation. J. Manag. Eng. 2006, 22, 168-175. [CrossRef] 
8. Conte, A.S.I.; Gransberg, D. Lean construction: From theory to practice. AACE Int. Trans. 2001, 22, CS101.

9. Thomassen, M.A.; Sander, D.; Barnes, K.A.; Nielsen, A. Experience and results from implementing lean construction in a large Danish contracting firm. In Proceedings of the 11th Annual Conference of the International Group for Lean Construction, Blacksburg, VA, USA, 22-24 July 2003; pp. 644-655.

10. Agbulos, A.; Mohamed, Y.; Al-Hussein, M.; AbouRizk, S.; Roesch, J. Application of lean concepts and simulation analysis to improve efficiency of drainage operations maintenance crews. J. Constr. Eng. Manag. 2006, 132, 291-299. [CrossRef]

11. Ikuma, L.H.; Nahmens, I.; James, J. Use of safety and lean integrated kaizen to improve performance in modular homebuilding. J. Constr. Eng. Manag. 2010, 137, 551-560. [CrossRef]

12. Abdel-Razek, R.H.; Abdel-Hamid, M. Labor productivity: Benchmarking and variability in Egyptian projects. Int. J. Proj. Manag. 2007, 25, 189-197. [CrossRef]

13. Kung, D.; Alex, D.P.; Al-Hussein, M.; Fernando, S. Application of lean thinking to improve the productivity of water and sewer service installations. Can. J. Civ. Eng. 2008, 35, 418-430. [CrossRef]

14. Mao, X.; Zhang, X. Construction process reengineering by integrating lean principles and computer simulation techniques. $J$. Constr. Eng. Manag. 2008, 134, 371-381. [CrossRef]

15. Farrar, J.M.; AbouRizk, S.M.; Mao, X. Generic implementation of lean concepts in simulation models. Lean Constr. J. 2004, 1, 1-23.

16. Conte, A.S.I. Last planner, look ahead, PPC: A driver to the site operations. In Proceedings of the 6th Annual Conference of the International Group for Lean Construction, Guarujá, Brazil, 13-15 August 1998; Volume 98, pp. 1-9.

17. Eriksson, P.E. Improving construction supply chain collaboration and performance: A lean construction pilot project. Supply Chain Manag. Int. J. 2010, 15, 394-403. [CrossRef]

18. Marhani, M.A.; Jaapar, A.; Bari, N.A.A.; Zawawi, M. Sustainability through lean construction approach: A literature review. Procedia-Soc. Behav. Sci. 2013, 101, 90-99. [CrossRef]

19. Song, L.; Liang, D. Lean construction implementation and its implication on sustainability: A contractor's case study. Can. J. Civ. Eng. 2011, 38, 350-359. [CrossRef]

20. Yahya, M.A.; Mohamad, M.I. Review on lean principles for rapid construction. J. Teknol. 2011, 54, 1-11. [CrossRef]

21. Alarcón, L.F.; Diethelm, S.; Rojo, O.; Calderon, R. Assessing the Impacts of Implementing Lean Construction. In Proceedings of the 13th Annual Conference of the International Group for Lean Construction, Sydney, Australia, 19-21 July 2005 ; pp. $387-393$.

22. AlSehaimi, A.O.; Fazenda, P.T.; Koskela, L. Improving construction management practice with the Last Planner System: A case study. Eng. Constr. Archit. Manag. 2014, 21, 51-64. [CrossRef]

23. Kim, D.; Park, H.-S. Innovative construction management method: Assessment of lean construction implementation. KSCE J. Civ. Eng. 2006, 10, 381-388. [CrossRef]

24. Mao, H.; Cheng, P. Design of Material Delivery System Based on Lean Construction. In Proceedings of the ICLEM 2010: Logistics for Sustained Economic Development: Infrastructure, Information, Integration, Chengdu, China, 8-10 October 2010; pp. 1793-1799. [CrossRef]

25. Ko, C.H. Application of lean production system in the construction industry: An empirical study. J. Eng. Appl. Sci. 2010, 5, 71-77. [CrossRef]

26. Nahmens, I.; Ikuma, L.H.; Khot, D. Kaizen and Job Satisfaction-A Case Study in Industrialized Homebuilding. Lean Constr. J. 2012,91-104. Available online: https://www.leanconstruction.org/media/library/id14/Kaizen_and_Job_Satisfaction_\%E2\%8 0\%93_A_Case_Study_in_Industrialized_Homebuilding.pdf (accessed on 14 April 2019).

27. Ballard, G.; Howell, G. Lean project management. Build. Res. Inf. 2003, 31, 119-133. [CrossRef]

28. Johansen, E.; Walter, L. Lean construction: Prospects for the German construction industry. Lean Constr. J. 2007, 3, 19-32.

29. Inokuma, A.; Aoki, M.; Shimura, M.; Nagayama, D.; Koizumi, C. Absence in the Provenance? Lean Construction and Its Applicability in Japan. In Proceedings of the 22nd Annual Conference of the International Group for Lean Construction, Oslo, Norway, 25-27 June 2014; pp. 15-26.

30. Nakagawa, Y.; Shimizu, Y. Toyota production system adopted by building construction in Japan. In Proceedings of the 12th Annual Conference of the International Group for Lean Construction, Helsingør, Denmark, 3-5 August 2004.

31. Sweis, G.; Hiyassat, M.; Al-Hroub, F.F. Assessing lean conformance by first-grade contractors in the Jordanian construction industry. Constr. Innov. 2016, 16, 446-459. [CrossRef]

32. Albalkhy, W.; Sweis, R. Lean Construction in the Jordanian Construction Industry: Implementation and Barriers. Master's Thesis, University of Jordan, Amman, Jordan, 2018.

33. Albalkhy, W.; Sweis, R. Assessing lean construction conformance amongst the second-grade Jordanian construction contractors. Int. J. Constr. Manag. 2019, 1-13. [CrossRef]

34. Albalkhy, W.; Sweis, R. Barriers to adopting lean construction in the construction industry: A literature review. Int. J. Lean Six Sigma 2020, 12, 136-210. [CrossRef]

35. Department of Statistics. Jordan in Figures 2016. 2016. Available online: http://dosweb.dos.gov.jo/wp-content/uploads/2017/1 1/JordanInFigures_2016.pdf (accessed on 14 March 2019).

36. El-Mashaleh, M.S.; Al-Smadi, B.M.; Hyari, K.H.; Rababeh, S.M. Safety management in the Jordanian construction industry. Jordan J. Civ. Eng. 2010, 4, 47-54.

37. Alkilani, S.Z.; Jupp, J.; Sawhney, A. Issues of construction health and safety in developing countries: A case of Jordan. Australas. J. Constr. Econ. Build. 2013, 13, 141. [CrossRef] 
38. Al-Momani, A.H. Construction delay: A quantitative analysis. Int. J. Proj. Manag. 2000, 18, 51-59. [CrossRef]

39. Sweis, G.; Sweis, R.; Hammad, A.A.; Shboul, A. Delays in construction projects: The case of Jordan. Int. J. Proj. Manag. 2008, 26, 665-674. [CrossRef]

40. Sweis, G. Factors Affecting Time Overruns in Public Construction Projects: The Case of Jordan. Int. J. Bus. Manag. 2013, 8, 120. [CrossRef]

41. Al-Momani, A.H. Construction cost prediction for public school buildings in Jordan. Constr. Manag. Econ. 1996, 14, 311-317. [CrossRef]

42. Assbeihat, J.M. Contractors' Actual Contribution During Projects' Implementation: Jordanian Construction. Sector. Dirasat Eng. Sci. 2005, 32, 1-7.

43. Al-Rifai, J.; Amoudi, O. Understanding the Key Factors of Construction Waste in Jordan. J. Civ. Eng. 2016, 10, 244-253. [CrossRef]

44. Krafcik, J.F. Triumph of the Lean Production System. MIT Sloan Manag. Rev. 2018, 30, 41. Available online: https://search. proquest.com/docview / 224963951?pq-origsite=gscholar (accessed on 13 January 2018).

45. Womack, J.P.; Jones, D.T. Beyond Toyota: How to root out waste and pursue perfection. Harv. Bus. Rev. 1996, 74, 1-16.

46. Womack, J.P.; Jones, D.T.; Roos, D. Machine That Changed the World; Simon and Schuster: New York, NY, USA, 1990.

47. Bertelsen, S.; Koskela, L. Construction beyond lean: A new understanding of construction management. In Proceedings of the 12th Annual Conference of the International Group for Lean Construction, Helsingør, Denmark, 3-5 August 2004.

48. Tezel, A.; Nielsen, Y. Lean construction conformance among construction contractors in Turkey. J. Manag. Eng. 2013, 29, 236-250. [CrossRef]

49. Koskela, L. Application of the New Production Philosophy to Construction; Stanford University: Stanford, CA, USA, 1992.

50. Koskela, L. An Exploration towards a Production Theory and Its Application to Construction; VTT Technical Research Centre of Finland: Espoo, Finland, 2000; Available online: https:/ / www.vttresearch.com/sites/default/files/pdf/publications/2000/P408.pdf (accessed on 14 April 2019).

51. Ballard, G. The Last Planner; Northern California Construction Institute: Monterey, CA, USA, 1994.

52. Ballard, G. The Last Planner System of Production Control. Ph.D. Thesis, The University of Birmingham, Birmingham, UK, 2000.

53. Gao, S.; Low, S.P. The Last Planner System in China's construction industry-A SWOT analysis on implementation. Int. J. Proj. Manag. 2014, 32, 1260-1272. [CrossRef]

54. Green, S.D.; May, S.C. Lean construction: Arenas of enactment, models of diffusion and the meaning of 'leanness'. Build. Res. Inf. 2005, 33, 498-511. [CrossRef]

55. Abdullah, S.; Abdul-Razak, A.; Abubakar, A.; Mohammad, I.S. Towards Producing Best Practice in the Malaysian Construction Industry: The Barriers in Implementing the Lean Construction Approach; Faulty of Engineering and Geoinformation Science; Universiti Teknologi: Padang, Malaysia, 2009.

56. Memon, S.A.; Rowlinson, S.; Sunindijo, R.Y.; Zahoor, H. Collaborative Behavior in Relational Contracting Projects in Hong Kong-A Contractor's Perspective. Sustainability 2021, 13, 5375. [CrossRef]

57. Awada, M.A.; Lakkis, B.S.; Doughan, A.R.; Hamzeh, F.R. Influence of Lean Concepts on Safety in the Lebanese Construction Industry. In Proceedings of the 24th Annual Conference of the International Group for Lean Construction, Boston, MA, USA, 20-22 July 2016.

58. Aziz, R.F.; Hafez, S.M. Applying lean thinking in construction and performance improvement. Alex. Eng. J. 2013, 52, 679-695. [CrossRef]

59. Bashir, A.M.; Suresh, S.; Oloke, D.A.; Proverbs, D.G.; Gameson, R. Overcoming the challenges facing lean construction practice in the UK contracting organizations. Int. J. Archit. Eng. Constr. 2015, 4, 10-18. [CrossRef]

60. Cano, S.; Delgado, J.; Botero, L.; Rubiano, O. Barriers and Success Factors in Lean Construction Implementation-Survey in Pilot Context. In Proceedings of the 23rd Annual Conference of the International Group for Lean Construction, Perth, Australia, 29-31 July 2015; pp. 631-641.

61. Fernandez-Solis, J.L.; Porwal, V.; Lavy, S.; Shafaat, A.; Rybkowski, Z.K.; Son, K.; Lagoo, N. Survey of motivations, benefits, and implementation challenges of last planner system users. J. Constr. Eng. Manag. 2013, 139, 354-360. [CrossRef]

62. Hamzeh, F.; Kallassy, J.; Lahoud, M.; Azar, R. The First Extensive Implementation of Lean and LPS in Lebanon: Results and Reflections. In Proceedings of the 24th Annual Conference of the International Group for Lean Construction, Boston, MA, USA, 18-24 July 2016.

63. Olamilokun, O. Investigating Facilitators and Barriers for Adopting Lean Construction Principles in the Nigerian Building Consulting Firms. Int. J. Innov. Res. Dev. 2015, 4, 234-239.

64. Olatunji, J.O. Lean-in-Nigerian construction: State, barriers, strategies and 'Go-To-Gemba'approach'. In Proceedings of the 16th Annual Conference of the International Group for Lean Construction, Manchester, UK, 16-18 July 2008; pp. 16-18.

65. Alarcón, L.F.; Diethelmand, S.; Rojo, O. Collaborative Implementation of Lean Planning Systems in Chilean Construction Companies. In Proceedings of the 10th Annual Conference of the International Group for Lean Construction, Gramado, Brazil, 6-8 August 2002; pp. 541-551.

66. Jorgensen, B.; Emmitt, S.; Bonke, S. Revealing Cultures and Sub-Cultures During the Implementation of Lean Construction. In Proceedings of the 12th Annual Conference of the International Group for Lean Construction, Helsingør, Denmark, 3-5 August 2004.

67. Sarhan, S.; Fox, A. Barriers to implementing lean construction in the UK construction industry. Built Hum. Environ. Rev. 2013, 6 , $1-17$. 
68. Seymour, D. Getting UK Construction People to Think Lean-Where to Start? A Case Study. In Proceedings of the 6th Annual Conference of the International Group for Lean Construction, Guarujá, Brazil, 13-15 August 1998.

69. Gao, S.; Low, S.P. Barriers to lean implementation in the construction industry in China. J. Technol. Manag. China 2014, 9, 155-173.

70. Alinaitwe, H.M. Prioritising lean construction barriers in Uganda's construction industry. J. Constr. Dev. Ctries. 2009, 14, 15-30.

71. Ayalew, T.; Dakhli, Z.; Lafhaj, Z. The Future of Lean Construction in Ethiopian Construction Industry. Int. J. Eng. Res. Technol. 2016, 5, 107-113.

72. Ahmed, M.E.A.; Wong, L.S. The Barriers of the Implementation of Lean Construction in Klang Valley, Malaysia. IOP Conf. Ser. Mater. Sci. Eng. 2020, 932, 1-13. [CrossRef]

73. Thakkar, H.; Shah, V.A. Barriers to Implementation of Lean Construction Techniques in Gujarat Construction Industry. Int. J. Eng. Technol. Manag. Res. 2021, 8, 17-24.

74. Gao, Z.; Aslam, M.; Smith, G. Strategies to Increase the Adoption Rate of Lean Construction. Epic Ser. Built Environ. 2020, 1, 364-372.

75. Brady, D.; Tzortopoulos, P.; Rooke, J. An Examination of the Barriers to Last Planner Implementation. In Proceedings of the 19th Annual Conference of the International Group for Lean Construction, Lima, Peru, 13-15 July 2011.

76. Kanafani, J.A. Barriers to the Implementation of Lean Thinking in the Construction Industry-The Case of UAE. Master's Thesis, University of Leicester, Leicester, UK, 2015.

77. Kothari, C.R. Research Methodology: Methods and Techniques; New Age International: New Delhi, India, 2004.

78. Yehuda, B.; Brooks, C.H. Survey response rate levels and trends in organizational research. Hum. Relat. 2008, 61, 1139-1160.

79. Samara, A.; Sweis, R.J.; Tarawneh, B.; Albalkhy, W.; Sweis, G.; Alhomsi, S. Sustainability management of international development projects by International Non-Governmental Organizations: The case of INGOs working with refugees in Jordan. Int. J. Constr. Manag. 2020,1-10. [CrossRef]

80. Khaba, S.; Bhar, C. Modeling the key barriers to lean construction using interpretive structural modeling. J. Model. Manag. 2017, 12, 652-670. [CrossRef]

81. Al-Hazim, N.; Salem, Z.A.; Ahmad, H. Delay and cost overrun in infrastructure projects in Jordan. Procedia Eng. 2017, 182, 18-24. [CrossRef]

82. Sweis, G.; Sweis, R.; Rumman, M.A.; Hussein, R.A.; Dahiya, S.E. Cost overruns in public construction projects: The case of Jordan. J. Am. Sci. 2013, 9, 134-141.

83. Assbeihat, J.M.; Sweis, G. Factors Affecting Change Orders in Public Construction Projects. Int. J. Appl. 2015,5 , 56-63.

84. Sweis, R.; Bisharat, S.M.; Bisharat, L.; Sweis, G. Factors affecting contractor performance on public construction projects. Life Sci. J. 2014, 11, 28-39.

85. Sekaran, U.; Bougie, R. Research Methods for Business: A Skill Building Approach; John Wiley \& Sons: Hoboken, NJ, USA, 2016.

86. Hair, J.F.; Black, W.C.; Babin, B.J.; Anderson, R.E.; Tatham, R.L. Multivariate Data Analysis; Prentice Hall: Upper Saddle River, NJ, USA, 1998.

87. Kachigan, S.K. Statistical Analysis: An Interdisciplinary Introduction to Univariate \& Multivariate Methods; Radius Press: Santa Fe, NM, USA, 1986.

88. Field, A. Discovering Statistics Using IBM SPSS Statistics; SAGE: Newbury Park, CA, USA, 2013.

89. Meier, U. A note on the power of Fisher's least significant difference procedure. Pharm. Stat. 2006, 5, 253-263. [CrossRef]

90. Garza, J.M.d.1.; Leong, M.-W. Last Planner technique: A case study. In Proceedings of the Construction Congress VI: Building Together for a Better Tomorrow in an Increasingly Complex World, Orlando, FL, USA, 20-22 February 2000; pp. 680-689.

91. Manuel, F.S.B.; Juan, R.P. Implementation of Lean-Kaizen in the human resource service process: A case study in a Mexican public service organisation. J. Manuf. Technol. Manag. 2010, 21, 388-410.

92. Zoe, R. Transferring Lean into government. J. Manuf. Technol. Manag. 2010, 21, 411-428.

93. Stehn, L.; Höök, M. Lean principles in industrialized housing production: The need for a cultural change. Lean Constr. J. 2008, 20-33. Available online: https://www.leanconstruction.org/media/docs/ktll-add-read/Lean_principles_in_industrialized_ housing_production_The_need_for_a_cultural_change.pdf (accessed on 14 April 2019).

94. Pekuri, A.; Herrala, M.; Aapaoja, A.; Haapasalo, H. Applying Lean in construction-cornerstones for implementation. In Proceedings of the 20th Annual Conference of the International Group for Lean Construction, San Diego, CA, USA, 18-20 July 2012; pp. 18-20.

95. Porwal, V.; Fernández-Solís, J.; Lavy, S.; Rybkowski, Z.K. Last Planner System Implementation Challenges. In Proceedings of the 18th Annual Conference of the International Group for Lean Construction, Haifa, Israel, 14-16 July 2010; pp. 548-556.

96. Raghavan, N.; Kalidindi, S.; Mahalingam, A.; Varghese, K.; Ayesha, A. Implementing Lean Concepts on Indian Construction Sites-Organisational Aspects and Lessons Learned. In Proceedings of the 22nd Annual Conference of the International Group for Lean Construction, Oslo, Norway, 25-27 June 2014; pp. 1181-1190.

97. Abbasi, G.Y.; Abdel-Jaber, M.S.; Abu-Khadejeh, A. Risk analysis for the major factors affecting the construction industry in Jordan. Emir. J. Eng. Res. 2005, 10, 41-47.

98. Liker, J.K. The Toyota Way: 14 Management Principles from the World's Greatest Manufacturer; McGrow-Hill: New York, NY, USA, 2004.

99. Marhani, M.A.; Jaapar, A.; Bari, N.A.A. Lean Construction: Towards enhancing sustainable construction in Malaysia. Procedia-Soc. Behav. Sci. 2012, 68, 87-98. [CrossRef] 
100. Wandahl, S. Lean Construction with or without Lean-Challenges of Implementing Lean Construction. In Proceedings of the 22nd Annual Conference of the International Group for Lean Construction, Oslo, Norway, 25-27 June 2014; pp. 97-108.

101. Small, E.P.; al Hamouri, K.; al Hamouri, H. Examination of Opportunities for Integration of Lean Principles in Construction in Dubai. Procedia Eng. 2017, 196, 616-621. [CrossRef]

102. Meiling, J.; Backlund, F.; Johnsson, H. Managing for continuous improvement in off-site construction: Evaluation of lean management principles. Eng. Constr. Archit. Manag. 2012, 19, 141-158. [CrossRef]

103. Salem, O.; Solomon, J.; Genaidy, A.; Luegring, M. Site implementation and assessment of lean construction techniques. Lean Constr. J. 2005, 2, 1-21.

104. Dulaimi, M.F.; Tanamas, C. The Principles of the Application of Lean Construction in Singapore. In Proceedings of the 9th Annual Conference of the International Group for Lean Construction, Singapore, 6-8 August 2001.

105. Sweis, R.J.; Ghalion, R.; El-Mashaleh, M.; Amayreh, I.; Niveen, A.-S.; Albalkhy, W. The effects of training and motivating employees on improving performance of construction companies: The case of Jordan. Int. J. Inf. Bus. Manag. 2019, 11, 179-211.

106. Abdi, L.A. Can Lean Construction Improve Project Performance in Jordan. Master's Thesis, University of Jordan, Amman, Jordan, 2016.

107. Al-Aomar, R. Analysis of lean construction practices at Abu Dhabi construction industry. Lean Constr. J. 2012, 105-121. Available online: https://www.leanconstruction.org/media/library/id11/Analysis_of_lean_construction_practices_at_Abu_ Dhabi_construction_industry.pdf (accessed on 14 April 2019).

108. Madsen, D.Ø.; Storsveen, M.; Klethagen, P.; Stenheim, T. The diffusion and popularity of Lean in Norway: An exploratory survey. Cogent Bus. Manag. 2016, 3, 1258132. [CrossRef]

109. Martins, J.; Cachadinha, N. An Exploratory Study of Lean Construction in Portugal-Owners and Designers Perspectives. In Proceedings of the 21st Annual Conference of the International Group for Lean Construction, Fortaleza, Brazil, 31 July-2 August 2013; pp. 285-295.

110. Alarcon, L.F.; Calderon, R. A Production Planning Support System for Construction Projects. In Proceedings of the 11th Annual Conference of the International Group for Lean Construction, Blacksburg, VA, USA, 22-24 July 2003.

111. Khanh, H.D.; Kim, S.Y. Barriers of Last Planner System: A Survey in Vietnam Construction Industry. J. Constr. Eng. Proj. Manag. 2013, 3, 5-11. [CrossRef]

112. Sweis, R.; Nasser, A.L.-H.; Alawneh, A.; Albalkhy, W.; Suifan, T.; Saa'da, R. ISO-9001 implementation and critical success factors of the Jordanian consulting engineering firms. Int. J. Product. Perform. Manag. 2021. [CrossRef]

113. Bekr, G.A. Study of Significant Factors Affecting Labor Productivity at Construction Sites in Jordan: Site Survey. GSTF J. Eng. Technol. (JET) 2016, 4, 92.

114. Khlaifat, D.M.; Alyagoub, R.E.; Sweis, R.; Sweis, G. Factors leading to construction projects' failure in Jordon. Int. J. Constr. Manag. 2019, 19, 65-78. [CrossRef] 